\title{
QUEEN'S
QNEIVERSITY
BELFAST
}

\section{Revisiting intersectionality for EU Anti-Discrimination Law in an economic crisis -a critical legal studies perspective}

Schiek, D. (2016). Revisiting intersectionality for EU Anti-Discrimination Law in an economic crisis -a critical legal studies perspective. Sociologia del Diritto, 2016(2). https://doi.org/10.3280/SD2016-002003

Published in:

Sociologia del Diritto

Document Version:

Publisher's PDF, also known as Version of record

Queen's University Belfast - Research Portal:

Link to publication record in Queen's University Belfast Research Portal

Publisher rights

Copyright ( FrancoAngeli

\section{General rights}

Copyright for the publications made accessible via the Queen's University Belfast Research Portal is retained by the author(s) and / or other copyright owners and it is a condition of accessing these publications that users recognise and abide by the legal requirements associated with these rights.

Take down policy

The Research Portal is Queen's institutional repository that provides access to Queen's research output. Every effort has been made to ensure that content in the Research Portal does not infringe any person's rights, or applicable UK laws. If you discover content in the Research Portal that you believe breaches copyright or violates any law, please contact openaccess@qub.ac.uk. 


\title{
Revisiting intersectionality \\ for $E U$ anti-discrimination law in an economic crisis - A critical legal studies perspective
}

\author{
by Dagmar Schiek*
}

\section{Introduction}

"One-dimensional equality is not enough" - this slogan captures a critical perspective on EU anti-discrimination law and policy, which challenges the neglect of intersectional inequalities. But how many dimensions does a critical legal discourse on anti-discrimination law need? Asking the question suggests that the intersectionality critique of equality policy takes a specific turn if based on a critical legal perspective. The article suggests that discrimination law (as a sub-section of the anti-discrimination discourse) should remain focused on discrimination events around the nodes gender/sex, ethnicity/'race', and disability/impairment - leaving the category of class to sociological discourse on intersectionality and to social and labour law, as a category to be distinguished from anti-discrimination law.

This distinction is particularly useful in times when the ongoing global economic crisis has led to a reinvigorated interest in social inequalities along class lines. In such times, the capacity to critique anti-crisis measures from the perspective of anti-discrimination law as an independent category is invaluable, as well as the willingness to expand this critique to new con-

\footnotetext{
* Queen's University Belfast. This article owes much to discussion with peers, in particular at the Equality is Not Enough conference in Antwerp (February 2015), convened by Alison Woodward, Daniël Cuypers, and Petra Meier; a day conference on Intersectionality in late 2013 in Brussels, convened by the same trio, where it was linked to a paper by Myra Marx Feree; and to discussions during the NCRE \& UC workshop on 1 April 2016 in Christchurch (New Zealand) on invitation by Annick Masselot; and specific comments by Ulrike M. Vieten. A critical review of "European Union Non-Discrimination Law and Intersectionality: Investigating the Triangle of Racial, Gender and Disability Discrimination" (Baer 2012) spurred the idea of this article, and anonymous referees' feedback contributed to the quality. The usual disclaimer applies.
}

Sociologia del diritto n. 2, 2016 
cepts of social policy developed in order to defy anti-crisis measures. The article develops this specific approach to intersectionality and EU antidiscrimination law from a critical legal scholar's perspective, which aims to maintain momentum by linking its argument to social movements.

The argument proceeds as follows: first, we sketch the specific perspective on critical legal studies. Based on the close interrelation of EU antidiscrimination law with social movements that shape this socio-legal field, we portray the contribution of social movements to EU anti-discrimination law and the resulting compartmentalisation, which at the same time limits the use of intersectionality in its application. Next, the article shortly summarises the proposal of a conceptual reconfiguration of existing EU antidiscrimination legislation. That reconfiguration is based on revealing the purpose of anti-discrimination law as its normative base, referring to Iris Marion Young's and Nancy Fraser's work. It re-interprets its existing provisions so as to refocus the field around the nodes sex/gender, 'race'/ethnicity, and impairment/disability.

This concept contradicts the current trend in discussing intersectionality, which follows the wider tendency to align policies combating poverty and generally improving working and living conditions of citizens on the one hand, and anti-discrimination policies on the other, and suggests a further expansion of discrimination grounds by the addition of 'class'.

Would the addition of 'class' as a discrimination ground under EU antidiscrimination law constitute a superior model for addressing intersectional inequalities than the proposed refocusing on the three nodes sex/gender, 'race'/ethnicity, and impairment/disability? In order to provide an experimental answer to this question, we analyse discrimination law discourses challenging austerity measures, establishing how far they respond to intersectional inequalities. We find that some intersectional inequalities, e.g. the situation of ethnic minority women, are once again neglected. The experiment thus demonstrates that a tightly focused anti-discrimination law exposes specific injustices, which are once again neglected as soon as the focus is lost.

The article concludes that EU anti-discrimination legislation, which is essentially focused on market inclusion, should refrain from using class as a "forbidden ground" in the same way as sex, race and disability. In this way EU anti-discrimination law will best serve as a standard for legislation and other action emanating from the public sphere which enhances intersectional inequalities. 


\section{A critical legal scholar's perspective}

Since critical legal studies is a field too wide to condense into one approach, the specific starting point to this methodological approach should be clarified. In my view, critical legal scholarship, if aligned with a left political project, should exploit the Janus-faced character of any legal order, which can be found in the space between lex and ius. Most European languages use different expressions for law mirroring these two Latin words. Lex stands for the positive law consisting of legislation and case law and overall the accepted doctrine. Lex tends to mirror the established consensus and as such support the societal status quo. Ius is frequently translated as justice. It holds out the promise that law may generate justice for all parts of the population. Obviously there can be a tension between lex and ius. Any critical interpretation of law works with this tension and challenges the established consensus by reference to justice, and thus creates space for changes in the law overall ${ }^{1}$. This approach maintains an original contribution of legal scholarship to critical studies, in contrast with approaches which only perceive law as a variable on the fringes of social policy debate, relegated to the role of a handmaiden for political science or sociological analysis.

Maintaining that legal scholarship can make an original contribution to critical studies should not be taken as a justification to neglect sociology in critical legal scholarship. After all, legal theory - even if exceedingly critical - without a reference point in practice will create little, if any momentum. In particular, critical legal scholarship should be aligned to social movements. Accordingly, the next section briefly discusses the contribution of social movements to EU anti-discrimination law and policy, and in particular to the capacity of EU anti-discrimination law to address intersectionality.

\section{Social movements, legislation and the use of intersectionality in EU anti- discrimination law}

Social movements and their use of the law were decisive for EU antidiscrimination law to develop. We all know that EU anti-discrimination law started with gender equality - the equal pay principle was part of the Treaty of Rome (cf. today's Article 157 TFEU), alongside the prohibition of nationality discrimination (today's Article 18 TFEU). Both were based

\footnotetext{
${ }^{1}$ For more references on this, see Schiek 2010a: 70-71, and Schiek 2012: 159-160.
} 
on the familiar mix of economic and social motives: discrimination was banned in order to prevent Member States and economic actors from enjoying competitive advantages by undercutting standards. Nowadays the equal pay clause is perceived as a starting point of the EU's wider body of sex equality law. That body was not only developed by the legislator. Its career started when female trade unionists and legal activists, disappointed with the progress towards implementing for the principle of equal pay for women and men, started to litigate before the Court of Justice and before national courts in order to convert into a practical tool what then was article 119 EEC (Hoskyns 1996: 64-70). The EU legislator followed suit and outlawed sex discrimination in employment ${ }^{2}$, complementing this body of directives by a guarantee of sex equality in the provision of goods and services ${ }^{3}$. The latter change attempted to close the gap between protection against sex discrimination and race discrimination in secondary EU law emerging in $2000^{4}$.

From 1999, when Eastern enlargement loomed large, and a right wing populist party became a government partner in Austria, the EU started legislating against racism ${ }^{5}$. As suggested by the Starting Line Group, which emerged from national movements focusing on racism as well as migration, the EU legislator shortly thereafter expanded its anti-discrimination law to disability, religion and belief, age, and sexual orientation (Schiek 2009b: 45 ), integrating concerns of disability rights' movements ${ }^{6}$, and promoters of gay equality ${ }^{7}$. Development of EU anti-discrimination policy, a term used by the EU Commission to encompass policies around Directives 2000/43

2 These are very numerous, but the main directives are Directive 2006/54 [OJ2006 L204/23] (initially Directives 76/207 and 75/117), and Directive 79/7[OJ1979 L6/24].

${ }^{3}$ Directive 2004/113/EC [OJ 2004 L373/37], see on this the ECJ ruling in C-236/09 (Test Achats) [2001] ECR I-773.

${ }^{4}$ Interestingly, the academic debate included voices chastising any critique of a lower level of protection for women against sex discrimination as "envious feminists" (Guiraudon 2009). While those stressing that "women are neither a minority nor a group" (e.g., Koukoulis-Spiliotopoulos 2005, reiterating the Women's Lobby's Slogan) were a minority in themselves, most academic authors criticised the hierarchies of equality. See, for example, Holzleithner 2005.

${ }^{5}$ Directive 2000/43/EC [OJ 2000 L180/22]; on its history see Niessen 2004.

${ }^{6}$ This term best captures the focus of the national and European level activist groupings engaging for the inclusion of disabled persons into society (Kemple et al. 2011), though its EU level emanation uses the name "European Disability Forum" (Mabbet 2005).

${ }^{7}$ Interestingly, the latter group remained hidden to a large extent in the negotiation procedures, with some authors indicating that this was related to some protagonists of wider equality agendas not being open about their homosexuality (Bell 2002: 35-42). 
and 2000/78 exclusively ${ }^{8}$, was henceforth supported by, and linked to, an EU level expert lobby, which was partly rooted in national and transnational movements (Verloo 2013).

It is important to note that this specific body of EU anti-discrimination legislation is aimed at combating discrimination in the market sphere. While much of the initial case law on sex discrimination (in contrast to case law on nationality-based discrimination) concerned Member States as employers, the states were addressed as gate-keepers for market access. Even where discrimination in social security issues, or access to funded transport, was at stake, these claims were ancillary to enabling employment market participation. The resulting critique of EU discrimination law as marketannexed (Somek 2011) misses its mark: in societies where inclusion is governed by markets, discrimination law has to address market discrimination effectively, lest it become irrelevant in social reality.

Up to this stage, social movements focusing on sex equality, disability rights, and the combat of racism and xenophobia specifically initiated and drove forward EU anti-discrimination law and policy. In line with the compartmentalisation of those movements, EU anti-discrimination policy proceeded along compartmentalised axes. The field was thus criticised as neglecting intersectional inequalities which are typical for many women's lives (Schiek \& Chege 2009; Schiek \& Lawson 2011).

While the EU Treaties and ensuing legislation had, from 1957, focused on nationality discrimination and sex discrimination, from 2000 EU legislation demanded that Member States outlaw employment discrimination on six grounds: sex, ethnic and racial origin, religion and belief, age, sexual orientation, and disability. Discrimination on grounds of racial and ethnic origin as well as on grounds of sex has to be outlawed beyond employment to varying degrees, among others, using anti-discrimination bodies as supporting enforcement. From 2000, the multiplicity of discrimination grounds ${ }^{9}$ invited the development of intersectionality (or multidimensionality) as an element of EU anti-discrimination policy ${ }^{10}$. The intersection be-

\footnotetext{
${ }^{8}$ For a recount of downgrading of gender equality to a secondary policy issue see Schiek $2010 \mathrm{~b}$.

${ }^{9}$ This term is used as a convenient abbreviation of "characteristics specified in positive discrimination law as those on grounds of which discrimination is forbidden". See, for example, Schiek et al. 2007: 4.

${ }^{10}$ The EU Commission embraced the opportunity to highlight the relative modernity of the EU's equality policy by funding some policy studies on this, with the highest funding awarded to Zarrehparvar \& Osander (2007). Their study did not systematically cover sex discrimination (Schiek 2009a). As a result, a new report on intersectionality by the now merged expert network on non-gender and gender equality is being produced under the authorship of Sandra Fredman (2016).
} 
tween discrimination on grounds of racial and ethnic origin on the one hand, and sex on the other, was to be addressed with priority, while in employment, multiple intersectional inequalities were to be addressed as well.

Nevertheless, EU- and national-level expert lobbies and movements remained curiously separate. To the present day, the European Women's Lobby and other gender-focused expert groups coexist with the European Network Against Racism and a number of other activist groups combating racist discrimination. The European Disability Rights movement, strengthened by the adoption of the UN Convention on the Rights of People with Disabilities, also maintains separate organisational structures. Since a legal field, such as discrimination law, is constructed not only by the law in the books, but also by actors using the law in social reality, this state of affairs can constitute a hindrance for EU anti-discrimination law to fully embrace intersectionality. It seems initially plausible, that one-point movements would maintain their initial focus, and continue to lobby for compartmentalised equalities. Gender activists, such as the European Women's Lobby, can be assumed to have a "gender first" attitude, while also supporting intersectionality strategies. After all, as the EU Directives also stress, women are most frequently affected by discrimination on more than one ground ${ }^{11}$. Thus, for gender equality experts, the intersectionality discourse constitutes an opportunity to widen the scope of policies supporting their cause (Verloo 2013: 909-910). As gender equality lobbying groups have a sound base in many EU Member States ${ }^{12}$, intersectionality claims can be expected to flourish. Any legal action group addressing sex discrimination could derive a legal base for claims from relying on intersectional discrimination, if representing women in areas such as access to education or healthcare, for which EU legislation allows sex discrimination to prevail at national levels.

Organisations roughly grouped under the umbrella of a European antiracism movement have demonstrated a commitment to multiple forms of discrimination by lobbying for Directive 2000/78, and more recently for a directive outlawing non-employment discrimination for the discrimination grounds covered by that directive ${ }^{13}$. They might also have an interest in stressing intersectionality, including of sex and racial and ethnic origin,

${ }^{11}$ Cf. Recital 14 and Article 17 of Directive 2000/43, and Recital 8 and Article 19 of Directive 2000/78 [OJ 2000 L303/16]. By contrast, not even the youngest Gender Directives refer to intersectional disadvantage (Schiek 2010b).

${ }^{12}$ For a critical assessment of the strength of any gender social movement in post socialist Member States see Havelková \& Oates-Indruchová 2014.

${ }^{13}$ COM (2008) 426 final (Schiek \& Mulder 2011), which the Commission plans to retable. 
since this would allow them to demonstrate that the privileged position of the latter discrimination in EU secondary law does not harm women's interests $^{14}$. However, those lobbying for a better response by the EU to racist discrimination might also feel that the EU still privileges sex discrimination in its primary law, e.g. through the specific clause on promoting sex equality in Article 23 Charter of Fundamental Rights for the European Union, and the gender mainstreaming clause in Article 8 TFEU, which is stronger than the obligation to combat discrimination on grounds of race and others (Article $10 \mathrm{TFEU})^{15}$. Also, anti-racism in the EU has a less prevalent national base than gender equality, which might feed a motivation to profile the cause of combating racism specifically.

The EU Disability Rights movement can be assumed to support intersectionality. After all, the UN CPRD is one of the first conventions to promote an intersectional approach. Further, politics for disabled people have a strong national base, as well as enjoying wider social acceptance than, for example, anti-racism politics, due to the potential of anyone to become disabled. Thus, we could assume that those organisations also are open to combating intersectional inequalities.

While this article cannot replace the lack of social movement research, which would enable us to present a full picture of the state of affairs, an evaluation of existing research renders some interesting observations. For example, data gathered by the EU funded EUROSPHERE project through document analysis and expert interviews in 16 countries has been interpreted as showing a limited commitment to intersectionality by "anti-racist and gender equality activists in Europe" (Pristed Nielsen 2012). The identification of intersectional inequalities as an important field of activity relies on utterances in documents both on paper and on web pages, and in interviews. Thus, the project did not investigate any advocacy or other activity on the ground. Nevertheless, Pristed Nielsen's data is very interesting in that she finds women's organisations systematically stressing the relevance of race and ethnicity, while anti-racist campaigners also mention gender at times. She also finds a discrepancy between EU and national level organisations: the latter display less awareness for intersectionality.

A more recent analysis of litigation strategies around Roma equality and gender equality (Jacquot \& Vitale 2015), on the other hand, confirms the observation that the separated structure of the lobby groups by-and-large results in compartmentalised anti-discrimination analysis. The European Women's Lobby is portrayed as following the development of the EU gen-

${ }^{14}$ For a critical perspective on this see Oprea 2009.

${ }^{15}$ For a wider critique see Hepple 2004. 
der policy and law, while stressing that women are not a minority, and focusing on gender mainstreaming as opposed to equality mainstreaming. The European Roma and Travellers' Forum, on the other hand, is reported as using intersectionality approaches in promoting the interests of Europe's Roma communities.

The European Disability Movement could be seen as most open to intersectionality in practice: even after the adoption of the UNCRPWD, the relevant organisations did not lobby for a separate directive - modelled on Directive 2004/113 for example - which would oblige Member States to outlaw disability discrimination beyond employment and, via the accepted legal construction of reasonable accommodation, would create a stronger legal base for accessibility politics. Instead, it remained part of the wider non-discrimination, lobbying for a Directive demanding the same policy on grounds of age, religion and belief, disability, and sexual orientation, which has not yet been enacted.

Overall, while EU anti-discrimination policy is still compartmentalised, at the EU-level, some national, lobbying groups support politics addressing intersectional inequalities. Accordingly, there is a base for expanding legal protections against intersectional inequalities.

EU legislation banning discrimination in the market place clearly can be interpreted in this direction (Schiek 2005). The recitals of the directives mention multiple-discrimination, and two of them even contain an obligation to report on the phenomenon. While case law in some common law jurisdictions has hesitated to acknowledge intersectional discrimination as legally wrong ${ }^{16}$, a teleological interpretation of EU secondary law, in line with the "dynamic interpretation" the Court of Justice typically uses in other fields, would suggest a coherent interpretation of the Directives to include a ban on intersectional discrimination (Schiek 2005). Accordingly, national courts on the European Continent and in Scandinavia have accepted intersectional discrimination more readily than Irish and British courts ${ }^{17}$. Nevertheless, the Court has as yet hesitated to employ its dynamic interpretation to this end, and advocates have not promoted intersectional discrimination in litigation strategies (Bullock \& Masselot 2012; Onufri 2014; Schiek 2009a; Schiek \& Mulder 2011). At the time of writing, the first reference explicitly addressing intersectionality (between male homosexuality and age) is pending before the Court of Justice (Case C-445/15 Parry $v$ Trinity College Dublin).

\footnotetext{
${ }^{16}$ See on this the coverage for UK law in Schiek \& Lawson 2011; Grabham et al. 2011; see also McColgan 2014: 54-59 and Monaghan 2011.

${ }^{17}$ Schiek 2009b. For national approaches see the national reports in this volume (coordinated by Susanne Burri and Hanneke van Eijken) and Skjeje 2009; Roseberry 2009.
} 


\section{Intersectionality and EU anti-discrimination legislation}

Feminist legal scholars have criticised anti-discrimination law for its lack of responsiveness to multiple inequalities involving gender/sex through intersectionality theory ${ }^{18}$. As the analysis of the wording of EU anti-discrimination legislation confirms, it is necessary for the achievement of its aims that intersectional discrimination is addressed. This is even more relevant in the fields addressed by EU legislation demanding that discrimination in market places is outlawed. Discrimination in market places results in exclusion from opportunities to participate in societal exchange. If these exclusions are based on intersections of, for example, ethnicity and gender, or disability and race, their socio-economic effect is bound to be more detrimental than instances of individual discrimination ${ }^{19}$. Thus, if intersectional discrimination is not acknowledged, the impact of EU antidiscrimination law is seriously diminished. At the same time, the sociological discourse on intersectionality appears to require a degree of differentiation that may deter the most determined anti-discrimination lawyer. The multiplication of categories accepted as relevant for intersectionality analysis, and their infinite combination, seems to establish an ever more diversified analytical field.

Law is increasingly seen as inadequate to cut through this thicket ${ }^{20}$. The unlimited multiplication of intersectional identities in sociological intersectionality discourses is not suitable for a critical legal project. This does not, however, mean that legal discourse, litigation, and court rulings have to disregard inequalities at the intersections of discrimination grounds that matter for their purposes.

Accordingly, the case has been made for refocusing the socio-legal field of market-centred EU anti-discrimination law, while expanding the number of discrimination grounds (Schiek 2011, 2016). Discrimination grounds such as sexual orientation, inability to bear children due to not having a womb while being categorised as female ${ }^{21}$, or becoming pregnant, can all be re-focused as gender discrimination, while discrimination on grounds of

${ }^{18}$ Intersectionality has been rephrased recently as a research programme spanning several disciplines (Cho et al. 2013), united by the mission to ensure recognition of specific disadvantage ensuing from intersections of different treatment, for example on grounds of sex and race, race and disability, or disability and sex.

${ }^{19}$ On the difference between cumulative and truly intersectional discrimination see Makkonen 2002 and Schiek 2009b.

${ }^{20}$ Accordingly, some fail to see any advantage of applying intersectionality to antidiscrimination law, e.g., Conaghan 2009.

${ }^{21}$ On the associated critique of the ECJ's judgment in Z. $v$ A Government Department, C-363/12 ECLI:EU:C:2014:159, see Schiek 2016: 60 with references. 
having a minority religion, an accent perceived as strange, or exhibiting colourings or clothing costumes being categorised as other, will be associated with ethnicity and race, and discrimination on grounds of being too slow in moving (whether on grounds of age, illness, or pregnancy), being not able to walk, or needing specific care, will be categorised as belonging to the disability node. This re-categorisation of discrimination grounds around nodes counteracts the arbitrariness of limitless proliferation of discrimination grounds. Such misguided proliferation could be accelerated by demanding to acknowledge intersections between any of the 21 EU discrimination grounds as specific groups protected by discrimination law. This would reduce the clarity and focus of EU anti-discrimination law to an extent that it would become impractical. Refocusing of EU antidiscrimination law could be supported in a merely positivistic way by pointing to the three UN anti-discrimination conventions, which focus on discrimination against women, racist discrimination, and discrimination (and other rights) of people with disabilities ${ }^{22}$.

However, this is not a very convincing justification. In developing defences against European social state retrenchment from the perspective of anti-discrimination law, it would appear necessary to develop a more sophisticated justification for omitting class from the relevant nodes for discrimination law (Baer 2012). After all, the discourse on intersectionality, after crossing the Atlantic as well as disciplines, debates gender, race, and class as the central categories for intersecting inequalities. Accordingly, the nodes concept promotes a differentiation between this sociological discourse and the legal instruments of anti-discrimination law. In order to justify that differentiation, it is necessary to turn to the normative base of antidiscrimination law, in particular of market-directed anti-discrimination law.

The normative basis of this aspect of anti-discrimination law, which is aimed at combating societal exclusion beyond political and public arenas, has been summarised as overcoming disadvantages related to ascribed otherness (Schiek 2000, 2002). Ascribed otherness works to categorise persons as heteronomous as opposed to autonomous. Ascribing otherness, or othering, in my view, is the specific mark of creating social disadvantage through market based discrimination. It is distinct from social inequalities associated with the class divide and poverty.

The ban on states differentiating between their citizens, which is part of most Western constitutions, and also reiterated in the European Convention on Human Rights (Article 14 and associated protocol), as well as in the Charter of Fundamental Rights for the European Union (Article 21), has

${ }^{22}$ See already Schiek 2002 and Schiek 2011. 
aspirations different from and beyond combating market based discrimination. It aims to ensure equality of citizens in the political process. Ever since nation states have been defined as including those who need to engage in dependent work to sustain themselves, constitutional discrimination clauses have banned discrimination on grounds of descent, property, and other emanations of class. The theme of political intersectionality, which has been explored by political scientists, is linked to this kind of equality in the political process (Krzsán et al. 2012; Verloo 2013). The ban on states' discrimination against their citizens is not the subject of this article, and also not of EU anti-discrimination legislation. Instead EU anti-discrimination legislation targets discrimination in market places. Thus, the question to be answered is: what exactly is the normative basis of the ban on discrimination in market places, which are constituted as different from the political agora.

Discrimination lawyers from the US and the UK, if arguing on the basis of doctrinal discourse, tend to answer this question uniformly for marketfocused and politically-focused discrimination law. Such intermingled explanations have difficulty distinguishing between ascribed otherness and class-based discrimination. For example, in 1996, Koppelman distilled as the basis of anti-discrimination law an obligation on the state to refrain from supporting the social construction of stigmatised classes (Koppelman 1996: 92ff.). While the aspiration of his book is only to legitimise antidiscrimination laws aimed at racism and sexism, including homophobic exclusion, he never denies that the class conflict - in the US American setting - underlies and informs race inequality ${ }^{23}$. Against this background, race discrimination laws may take the place of social welfare laws, and vice versa. The insistence on an anti-discrimination discourse has been explained by the US American aversion against social state paradigms in the context of analysing disability discrimination law (Quinn \& Flynn 2012). As a more recent recount states, the harm combated by discrimination law consists of categorising persons by way of stereotypes and stigma (Khaitan 2015). Again, this discourse relates to positive anti-discrimination law, but the same reasoning could be expanded to class discrimination.

In identifying the purpose of market focused anti-discrimination law, we must look beyond the state however. As mentioned, EU anti-discrimination legislation does this by focusing at horizontal relationships. What is the purpose of going beyond state-citizen relations in anti-discrimination law then?

${ }^{23}$ See, for example, Koppelman 1996: 97-100 with reference to Myrdal. 
The theoretical frame frequently adopted is the one developed by Iris Marion Young (2009) ${ }^{24}$. Young identified as the main purpose of antidiscrimination law the need to address positional difference in societies. These derive from interactions based on categorical distinctions in hierarchies of status and privilege, thus producing durable inequalities. In Young's view, these inequalities are characterised by divisions of labour, as well as normalisation. Young's academic position changed during her lifetime (Martínez-Bascuñán 2012: 136-158): while she stressed the equal rank of distributive justice and the politics of difference in her earlier work, her later work - for example mirrored in her posthumous publication of 2009 focuses on structural inequalities as more relevant for social ordering and social justice. Young has thus moved more and more towards a Marxist conception of social justice, furthering this thinking by adding recognition for the gendered division of labour as a fundamental social structure. Her conceptualisation of normalisation which serves to suppress the recognition of bodily difference also offers a starting point to convey disability as a structural inequality. The politics of difference captures the specific dimension of racialising class in US society as a category different from social group formation along the class divide. While, for Young, social class certainly is among those social divisions whose recognition is a precondition of achieving social justice, her work also allows for conceptualisation of the relevance of central categories for anti-discrimination law. It is thus an excellent starting point for establishing the normative purpose of antidiscrimination law. It allows us to recognise that establishing groups along the categorical differences based on division of labour, normalisation, and construction of bodily and cultural difference, is of immense relevance for distributive decisions - even though distribution is not the only dynamic by which social justice is defined.

Taking into account Nancy Fraser's critique of Young's work enables us to move closer to the normative goal of market-focused anti-discrimination law in particular. Fraser $(2000 ; 2007)$ offers a differentiation between the "new social movements", promoting feminism and anti-racism, and the class divide in the world after socialism. While the class divide was the promoter of policies aiming to equalise social injustice by redistribution, racism, sexism, and (implicitly) ableism, demand other answers, which in Fraser's view are based on recognition. However, instead of proclaiming redistribution and recognition as incommensurable, the redistributive character of anti-discrimination policy is recognised. The difference between

${ }^{24}$ For a variety of reflections on Iris Marion Young from European perspectives see Vieten 2014. 
the socialist social policy, and social policy after socialism, consists of the fact that the post-socialist policy fields defined by feminist and antiracist movements, for example, generate policies recognising difference instead of equalising social divides such as the class divide, or between the rich and the poor (Martínez-Bascuñán 2012: 159-167).

Using an alternative distinction, one could characterise those categories addressed by anti-discrimination law as different from fundamental cleavages dividing societies as a consequence of fundamental change ${ }^{25}$. Examples for such cleavages include that between religion and secularity (after Europe's secularisation), rural areas and cities, as well as class divides after industrialisation. Cultural difference, while leading to stable inequalities based on ascribing difference, are of a different quality altogether.

Anti-discrimination law addresses the ill of exclusion in the market place based on a specific kind of de-recognition. These are de-recognitions that are not linked to any rationality, and appear as archaic if used as a base for differentiation. At the same time, these de-recognitions constitute elements of persons' identities outside the categories of the market (such as consumer identity, class identity, or poverty) which they are not expected to suppress or neglect. Banning such cultural exclusion in the market place as the main distributive mechanism of Western societies, discrimination law has distributional consequences. However, it will not require assimilation, since the differences are seen as expressions of human diversity to be respected and cherished. These are the conceptual reasons for not using class as a discrimination ground in European anti-discrimination law, which impact on the concept of intersectionality in law ${ }^{26}$.

When those theorising European anti-discrimination law regimes define as its purpose the overcoming of structural disadvantage (Fredman 2011: 28-38; McColgan 2014: 36-37), this might suggest aligning antidiscrimination law and policy with the overarching aims of social policy in general. Thus, anti-discrimination law and policy have been criticized because this field of law does not achieve the same kind of social justice as classical European policies aimed at de-commodification (Somek 2011). This critique is not convincing in the light of the normative dimensions developed above. It is not the goal of anti-discrimination law to promote the same dimension of social justice as social law and policy addressing distributive and participatory injustices of capitalism. Instead, antidiscrimination law addresses exclusions of a different kind, and must complement, but not replace, social and welfarist policies.

${ }^{25}$ Gerhards \& Lengfeld 2015: 45-47, with reference to Stein Rokkan.

${ }^{26}$ See for a similar differentiation Verloo 2006. 
These deliberations justify focusing EU anti-discrimination law, especially its market based branch, on nodes around gender, race, and disability. The nodes model provides a normative frame for acknowledging discrimination ills. It also provides a structure which pictures overlap between those nodes as the normal state of affairs. This suggests that discrimination on grounds of such overlap, or intersections, is accepted as discrimination to be challenged by law.

5. Current uses of intersectionality: class, poverty, and general socioeconomic disadvantage as discrimination grounds?

This refocus is not aligned with all recent uses of intersectionality. As stressed initially, the journey of intersectionality as an analytical category from its origins in legal scholarship and advocacy, to sociological and political science analysis, implies the heightened relevance of class. In parallel, the use of anti-discrimination law in international human rights discourse, as well as in international labour law, has changed to include a new focus on poverty and general socio-economic disadvantage. The "transformation" of human rights has been developed as a research agenda aligning general human rights discourses with those developed in anti-discrimination law (Fredman 2008). In analysing the practical policies of the ILO, the "inclusive equality framework" is praised for its potential to converge agendas pursued by labour law and anti-discrimination law respectively (Sheppard 2015: 257-260). The increased relevance of socio-economic inequalities in the European Union and elsewhere is underlined by public reactions to the global economic crisis. International financial institutions, partly in collaboration with European institutions, demand that states reduce institutions established to guarantee social inclusion. The resultant change is felt most acutely in Continental Europe, where promoting social equality at large has been an acknowledged task of the state for a long time ${ }^{27}$.

Against this background, it is not surprising that intersectionality is developed beyond the traditional field covered by anti-discrimination law. The analytical framework is no longer focused on enhancing recognition for specific disadvantage inflicted on women of colour through systemic discrimination. Instead, intersectionality is seen as promoting "more flexible and open-ended categories in anti-discrimination law" (Sheppard 2015: 256). Thus, intersectional discrimination could be deemed to exist if wom-

${ }^{27}$ The resulting changes are well-documented; see for example Schraad-Tischler 2016; Vlad \& Tache 2013. 
en of lower socio-economic status are specifically affected by a certain governmental policy.

In Europe, such strategies to use intersectionality abound. For example, in France, equality activists, when discussing gender quotas, promoted using the intersection of class and gender (but not religion, race, and gender) as a category to assess their adequacy at addressing relevant social problems (Lépinard 2013). Similarly, class and gender are being introduced as additional categories to be considered in anti-racist policies (Tiberj \& Michon 2013). Further studies of anti-crisis measures addressing the gendered character of youth unemployment purport to address the intersection of unemployment and gender (Colombo \& Rebughini 2015).

Does this trend render irrelevant any refocusing on the purpose of antidiscrimination law? Would a node-focused intersectionality analysis have any advantage over the wider one, focusing on class or poverty instead?

\section{Anti-crisis measures and discrimination law}

Legal challenges to anti-crisis measures in the EU can be approached as a fictional laboratory in order to answer this question. The laboratory is fictional, because human rights challenges to anti-crisis measures have to rely on the existing legislation. Accordingly, they cannot rely on any prohibition of class discrimination if using EU anti-discrimination law, though they can use origin or wealth if contained in national human rights instruments. However, would the addition of class as a discrimination ground improve the quality of the challenge?

As long as austerity measures are challenged using anti-discrimination law (Kilpatrick 2014), these challenges may, for example, use the extent to which austerity measures increase female poverty (Lahey \& Villota 2013). Such challenges can have a dual motive; on the one hand, the justiciability of anti-discrimination sections of human rights catalogues may enable litigants to expose the wider injustices inflicted by austerity measures. This would be an instrumental use of gender equality law. Similarly, instrumental uses of UN human rights conventions (Fredman \& Goldblatt 2015) might be motivated by the desire to achieve specific reports requiring governments to change austerity measures, adding weight to the political critique of those. Gender-related challenges of austerity measures might also be motivated by a desire to expose the specific injustices inflicted by ignoring gendered inequality. Accordingly, the challenge of austerity measures

might also be aimed at changing the specific measure, in order to distribute the consequences of austerity more equally between women and men. If so 
motivated, the critique can even address the situation of differently positioned women, and consider whether, for example, ethnic minority women, or disabled women are more severely affected than white or able-bodied women. This would constitute a veritable intersectionality analysis of austerity measures (Goldblatt 2015).

Such a discrimination law analysis would expose discriminatory elements of social state retrenchment. We use the term 'social state' deliberately here, instead of the more commonly used term 'welfare state ${ }^{28}$. The latter term originates from the approach taken to "benefits" in the so-called liberal welfare states ${ }^{29}$. Under this approach, welfare is mainly restricted to the pay-out of strictly means tested benefits. In constitutional social states, by contrast, citizens not only have a constitutional claim to "benefits", but are also included in social institutions which then constitute societies which are inclusive overall.

If it is correct that women are poorer than men on average, or that those racialised because they are in an ethnic minority are excluded from employment opportunities, retrenching institutions that ensure inclusion, or reducing the general level of payments for those who are not able to earn sufficiently through work, will affect relatively more women, persons ascribed minority status, and even more severely impact on women ascribed ethnic minority status. Accordingly, with careful statistical work, the first step of an indirect discrimination challenge could be accomplished. Of course, the austerity measure could still be justified, if it pursues a valuable objective, such as enabling the relevant state to obtain funds it desperately needs. The justification would fail if there would be less-discriminatory alternatives. For example, in states which also provide specific benefits for proportions of the population, in which women or ethnic minorities are not overrepresented, those benefits could be reduced instead of those for the poorest. In this way, austerity would have less discriminatory effects. While this may seem a perverse result at first hand, excluding additional discriminatory effects of social state entrenchment is a worthwhile exercise if we accept that the state, just as market participants, should not reinforce systemic discrimination. This critique, although more intellectually and analytically challenging, exposes more precisely the discriminatory effects of social state entrenchment, instead of just utilising anti-discrimination law to support general social policies.

${ }^{28}$ See for example Castles et al. 2010.

${ }^{29}$ On the notions of 'welfare state' see Esping-Andersen $(1990 ; 1999)$. See also Arts \& Gelissen 2010 and subsequent chapters in the same volume. 
Now, what would be achieved if class, or living below the poverty line, were discrimination grounds? First, it would be easier to challenge austerity measures with discrimination law, as the difficulties of launching a discrimination claim would be avoided. However, this advantage would only be gained if social class could be defined with sufficient precision for discrimination law. Such precision might be achieved, for example, by reference to household income not exceeding the lowest quartile of the population. Such a definition would possibly have negative gender effects, because the lack of command over income within households would be ignored. However, challenges would be easier than if applying a precise notion of antidiscrimination law.

This fictional assessment exposes that the gains of including class in anti-discrimination law are, indeed, limited. If the aim is to attack state action, the constitutional and international human rights instruments already ban states from differentiation on the basis of income. Thus, these challenges could be raised at present, without diluting anti-discrimination law.

If the aim is to provide an analytical framework of assessing the specific exclusion of, for example, poor women, this aim is also achieved by applying sex discrimination law to social state entrenchment. Social state entrenchment will hardly affect rich women. However, in many states it will affect ethnic minority women more severely than white women. This conclusion could be achieved by applying an intersectionality analysis on the basis of existing anti-discrimination law.

The advantage of the more challenging standards would be a more targeted critique of social state entrenchment, which links with the critique of supposedly gender-blind social states in better years. Just as, for example, the Beveridge model is partly less exclusive of women, in offering access to services such as health care irrespective of being over a threshold in labour market inclusion or through family links, social state entrenchment exercised mindful of women's specific situation will be less discriminatory. Discrimination argumentation cannot be diluted into a mere social policy argument, while a precise application of its categories is still required.

The fictional experiment thus demonstrates that enriching antidiscrimination legislation by class as a discrimination ground has limited advantages for legal intersectionality analysis. Most likely the disadvantages outweigh the advantages. 


\section{Conclusion}

In order to make anti-discrimination law more suitable for addressing intersectional inequalities, it is necessary to avoid overstretch ${ }^{30}$, and to refocus anti-discrimination law. This refocusing should avoid including class or poverty as categories used by positive EU discrimination law. Such an expansion of "discrimination grounds" would result in the loss of focus of anti-discrimination law on a specific wrong. This wrong consists of social disadvantage through market based discrimination triggered by ascribed otherness. Wider aims of social justice, such as overcoming poverty and social exclusion altogether, cannot be achieved by anti-discrimination law. Anti-discrimination law remains a suitable and necessary instrument for addressing any discriminatory bias within policies and law attempting to overcome poverty and exclusion. This even holds true if austerity measures are used to legitimise further re-entrenchment of social state law.

Accordingly, the categories developed for sociological analyses of inequalities at the intersections are wholly unsuitable for legal analyses of intersectionality. For legal analysis, the mission of anti-discrimination law is decisive. This mission requires maintaining focus on the specific aims of combating exclusion on the basis of ascribed personality traits beyond market-related categories. Maintaining this focus is a precondition for maintaining anti-discrimination law's application to market-based exchange and the public sector alike. In societies increasingly determined by market exchange, this focus also maintains the relevance of anti-discrimination law for social reality.

\section{References}

Arts, Wil A., \& John Gelissen, 2010. Models of the Welfare State. In Francis G. Castles Stephan Leibfried, Jane Lewis, Herbert Obinger \& Christopher Pierson (eds.), The Oxford Handbook of the Welfare State. Oxford: Oxford University Press.

Baer, Susanne, 2012. Book Review: European Union Non-Discrimination Law and Intersectionality: Investigating the Triangle of 'Race', Gender and Disability, Dagmar Schiek \& Anna Lawson (eds.). Farnham: Ashgate, 2011. Common Market Law Review, 49, 4: 1495-1497.

Bell, Mark, 2002. Anti-Discrimination Law and the European Union. Oxford: Oxford University Press.

\footnotetext{
${ }^{30}$ The term is borrowed from McColgan 2014: 63-65.
} 
Bullock, Jess, \& Annick Masselot, 2012. Multiple Discrimination and Intersectional Disadvantages: Challenges and Opportunities in the European Union Legal Framework. Columbia Journal of European Law, 19, 1: 57-82.

Castles, Francis G., Stephan Leibfried, Jane Lewis, Herbert Obinger \& Christopher Pierson (eds.), 2010. The Oxford Handbook of the Welfare State. Oxford: Oxford University Press.

Cho, Sumi, Kimberlé W. Crenshaw \& Leslie McCall, 2013. Towards a Field of Intersectionality Studies: Theory, Applications and Praxis. Signs: Journal of Women in Culture and Societies, 38, 4: 785-810.

Colombo, Enzo, \& Paola Rebughini, 2015. Italian Young People Coping with the Consequences of Economic Crisis: an Intersectional Analysis. Oñati Socio-Legal Series, 5, 4: 1031-1049.

Conaghan, Joanne, 2009. Intersectionality and the Feminist Project in Law. In Emily Grabham, Davina Cooper, Jane Krishnadas \& Didi Herman (eds.), Intersectionality and Beyond: Law, Power and the Politics of Location. London: RoutledgeCavendish.

Esping-Andersen, Gøsta, 1990. The Three Worlds of Welfare Capitalism. Cambridge: Polity Press.

—, 1999. Social Foundations of Post-Industrial Economies. Oxford: Oxford University Press.

Fraser, Nancy, 2000. Rethinking Recognition. New Left Review, 3, 1: 107-120.

-, 2007. Re-Framing Justice in a Globalizing World. In Terry Lovell (ed.), (Mis)Recognition, Social Inequality and Social Justice. London: Routledge.

Fredman, Sandra, 2008. Human Rights Transformed. Oxford: Oxford University Press.

—, [2002]2011. Discrimination Law. Oxford: Oxford University Press.

—, \& Beth Goldblatt, 2015. Gender Equality and Human Rights. New York: United Nations Women.

-, 2016. Intersectional Discrimination in EU Gender Equality and NonDiscrimination Law. Brussels: European Commission.

Gerhards, Jürgen, \& Holger Lengfeld, 2015. European Citizenship and Social Integration in the European Union. New York: Palgrave.

Goldblatt, Beth, 2015. Intersectionality in International Anti-Discrimination Law: Addressing Poverty in Its Complexity. Osgoode Hall Law Journal, 53, forthcoming.

Grabham, Emily, Davina Cooper, Jane Krishnadas \& Didi Herman (eds.), 2011. Intersectionality and Beyond: Law, Power and the Politics of Location. London: Routledge-Cavendish.

Guiraudon, Virginie, 2009. Equality in the Making. Implementing EU NonDiscrimination Law. Citizenship Studies, 13, 5: 527-541.

Havelková, Hana, \& Libora Oates-Indruchová (eds.), 2014. The Politics of Gender Culture under State Socialism: An Expropriated Voice. London: Routledge.

Hepple, Bob, 2004. Race and Law in Fortress Europe. Modern Law Review, 67, 1: 115. 
Holzleithner, Elisabeth, 2005. Mainstreaming Equality: Dis/Entangling Grounds of Discrimination. Transnational Law \& Contemporary Problems, 14, 3: 927-950.

Hoskyns, Catherine, 1996. Integrating Gender: Women, Law and Politics in the European Union. London: Verso.

Jacquot, Sophie, \& Tommaso Vitale, 2015. Law as Weapon of the Weak? A Comparative Analysis of Legal Mobilization by Roma and Women's Groups at the European Level. Journal of European Public Policy, 21, 4: 587-604.

Kemple, Mariam, Fatima Ahmad \& Suraj Girijashanker, 2011. Shaping Disability Rights through Shaping the Disability Movement. Journal of Human Rights Practice, 3, 3: 355-363.

Khaitan, Tarunabh, 2015. A Theory of Discrimination Law. Oxford: Oxford University Press.

Kilpatrick, Claire, 2014. Are the Bailouts Immune to EU Social Challenge Because They Are Not EU Law? European Constitutional Law Review, 10, 3: 393-421.

Koppelman, Andrew, 1996. Antidiscrimination Law and Social Equality. New Haven and London: Yale University Press.

Koukoulis-Spiliotopoulos, Sophia, 2005. The Amended Equal Treatment Directive (2002/73): An Expression of Constitutional Principles/Fundamental Rights. Maastricht Journal of European and Comparative Law, 12, 4: 327-368.

Koutnatzis, Stylianos-Ioannis G., 2005. Social Rights as a Constitutional Compromise: Lessons from Comparative Experience. Columbia Journal of Transnational Law, 44, 1: 74-133.

Krzsán, Andrea, Hege Skjeje \& Judith Squire (eds.), 2012. Institutionalizing Intersectionality: The Changing Nature of European Equality Regimes. Basingstoke: McMillan.

Lahey, Kathleen A., \& Paloma Villota, 2013. Economic Crisis, Gender Equality and Policy Responses in Spain and Canada. Feminist Economics, 19, 3: 82-107.

Lépinard, Éléonore, 2013. For Women Only? Gender Quotas and Intersectionality in France. Politics \& Gender, 9, 1: 276-298.

Mabbet, Deborah, 2005. The Development of Rights-Based Social Policy in the European Union: The Example of Disability Rights. Journal of Common Market Studies, 43, 1: 97-120.

Makkonen, Timo, 2002. Multiple, Compound and Intersectional Discrimination: Bringing the Experiences of the Most Marginalized to the Fore. Turku: Institute for Human Rights Åbo Akademi University.

Martínez-Bascuñán, Máriam, 2012. Género, emancipación y diferencia(s). La teoría política de Iris Marion Young. Madrid: Plaza y Valdés.

McColgan, Aileen, 2014. Discrimination, Equality and the Law. Oxford: Hart.

Monaghan, Karon, 2011. Multiple and Intersectional Discrimination in EU Law. European Anti-Discrimination Law Review, 13: 20-32.

Niessen, Jan, \& Isabelle Chopin (eds.), 2004. The Development of Legal Instruments to Combat Racism in a Diverse Europe. Leiden: Martinus Nijhoff.

Onufrio, Maria Vittoria, 2014. Intersectional Discrimination in the European Legal Systems: Toward a Common Solution? International Journal of Discrimination and the Law, 14, 2: 126-140. 
Oprea, Alexandra, 2009. Intersectionality Backlash: A Romani Feminist's Response. Roma Rights, 2: 21-24.

Pristed Nielsen, Helene, 2012. Joint Purpose? Intersectionality in the Hands of Antiracist and Gender Equality Activists in Europe. Ethnicities, 13, 3: 276-294.

Quinn, Gerard \& Eilinóir Flynn, 2012. Transatlantic Borrowings: The Past and Future of EU Non-Discrimination Law and Policy. The American Journal of Comparative Law, 60, 1: 23-48.

Roseberry, Lynn, 2009. Religion, Ethnicity and Gender in the Danish Headscarf Case. In Dagmar Schiek \& Victoria Chege (eds.), European Union NonDiscrimination Law: Comparative Perspectives on Multidimensional Equality Law. Abingdon \& New York: Routledge-Cavendish.

Schiek, Dagmar, 2000. Differenzierte Gerechtigkeit. Baden-Baden: Nomos.

-, 2001. Artikel 20 Abs. 1-3 V: Sozialstaat. In Ekkehard Stein (ed.), Alternativkommentar zum Grundgesetz. Neuwied et al: Luchterhand.

-, 2002. A New Framework on Equal Treatment of Persons in EC Law? Directives 2000/43/EC, 2000/78/EC and 2002/73/EC Changing Directive 76/207/EEC in Context. European Law Journal, 8, 2: 290-314.

-, 2005. Broadening the Scope and the Norms of EU Gender Equality Law: Towards a Multidimensional Conception of Equality Law. Maastricht Journal of European and Comparative Law, 12, 4: 427-466.

- , Lisa Waddington \& Mark Bell, 2007. Introduction. In Dagmar Schiek, Lisa Waddington \& Mark Bell (eds.), Cases Materials and Text on European, International and National Non-Discrimination Law. Oxford: Hart.

—, 2009a. Multiple Discrimination in EU Law. In Susanne Burri \& Dagmar Schiek (eds.), Multiple Discrimination in EU Law: Opportunities for Legal Responses to Intersectional Gender Discrimination? Brussels: European Commission.

-, 2009b. From European Union Non-Discrimination Law towards Multidimensional Equality Law for Europe. In Dagmar Schiek \& Victoria Chege (eds.), European Union Non-Discrimination Law. Comparative Perspectives on Multidimensional Equality Law. London: Routledge.

—, \& Victoria Chege (eds.), 2009. European Non-Discrimination Law. Comparative Perspectives on Multidimensional Equality Law. London: Routledge.

-, 2010a. Is There a Social Ideal of the European Court of Justice? In Ulla Neergaard, Ruth Nielsen \& Lynn Roseberry (eds.), The Role of Courts in Developing a European Social Model - Theoretical and Methodological Perspectives. Copenhagen: DJØF Publishing.

-, 2010b. EU Non-Discrimination Law \& Policy: Gender in the Maze of Multidimensional Equalities. In Christine Hohmann-Dennhardt, Marita Körner \& Reingard Zimmer (eds.), Geschlechtergerechtigkeit. Liber Amicorum Heide Pfarr. Baden-Baden: Nomos.

-, 2011. Organising EU Non-Discrimination Law Around the Nodes of 'Race', Gender and Disability? In Dagmar Schiek \& Anna Lawson (eds.), European Union Non-Discrimination Law and Intersectionality: Investigating the Triangle of Racial, Gender and Disability Discrimination. Farnham: Ashgate. 
—, \& Anna Lawson (eds.), 2011. EU Non-Discrimination Law and Intersectionality: Investigating the Triangle of Race, Gender and Disability. Farnham: Ashgate.

—, \& Jule Mulder, 2011. Intersectionality and EU Law: A Critical Appraisal. In Dagmar Schiek \& Anna Lawson (eds.), EU Law and Intersectionality: Investigating the Triangle of Racial, Gender and Disability Discrimination. Farnham: Ashgate.

-, 2012. Social Ideals of the Court of Justice of the European Union. In Tatjana Evas, Ulrike Liebert \& Christopher Lord (eds.), Multilayered Representation in the European Union: Parliaments, Courts and the Public Sphere. Baden-Baden: Nomos.

—, 2016. Intersectionality and the Notion of Disability in EU Discrimination Law. Common Market Law Review, 53, 1: 35-64.

Schraad-Tischler, Dagmar, 2016. Social Justice in the EU - Index Report 2015. Düsseldorf: Bertelsmann Foundation.

Sheppard, Colleen, 2015. Inclusive Equality and New Approaches to Discrimination in Transnational Labour Law. In Adelle Blackett \& Anne Trebilcock (eds.), Research Handbook on Transnational Labour Law. Cheltenham: Edward Elgar.

Skjeje, Hege, 2008. Multiple Equality Claims in the Practice of the Norwegian AntiDiscrimination Agencies. In Dagmar Schiek \& Victoria Chege (eds.), European Union Non-Discrimination Law: Comparative Perspectives on Multidimensional Equality Law. Abingdon \& New York: Routledge-Cavendish.

Somek, Alexander, 2011. An Essay on EU Anti-Discrimination Law. Oxford: Oxford University Press.

Tiberj, Vincent, \& Laure Michon, 2013. Two-Tier Pluralism in 'Colour-Blind' France. West European Politics, 36, 3: 580-596.

Verloo, Mieke, 2006. Multiple Inequalities, Intersectionality and the European Union. European Journal of Women's Studies, 13, 3: 211-228.

—, 2013. Intersectional and Cross-Movement Politics and Policies: Reflections on Current Practices and Debates. Signs: Journal of Women in Culture and Society, 38, 4: 893-915.

Vieten, Ulrike M. (ed.), 2014. Revisiting Iris Marion Young on Normalisation, Inclusion and Democracy. London: Macmillan.

Vlad, Dumitrache \& Ilean Tache, 2013. Impact of Global Economic Crisis on the European Welfare States. European Research Studies, 16, 3: 3-17.

Young, Iris Marion, 2009. Structural Injustice and the Politics of Difference. In Emily Grabham Davina Cooper, Jane Krishnadas \& Didi Herman (eds.), Intersectionality and Beyond. Oxon: Routledge-Cavendish.

Yuval-Davis, Nira, \& Floya Antyas, 1983. Gender, Race and Class. London: Polity Press.

Zarrehparvar, Mandana, \& Caroline Osander, 2007. Tackling Multiple Discrimination: Practices, Policies and Laws. Brussels: European Commission. 